\title{
Investigating the Effect of Perceived Professional Ethics on Customer Loyalty Considering the Mediating Role of Perceived Reputation and Trust
}

\section{(Case Study: Asia-Pharma Manufacturing and Trading Company in Herat Province)}

\author{
Mohammad Rafi Rahimi ${ }^{\text {a, }}$ Alireza Haddadian ${ }^{\text {b }}$, Mohammad Mehdi Farahi ${ }^{\mathrm{c}}$ \\ ${ }^{a}$ Master in Public Administration, Development Orientation and Human resources of Ferdowsi University of Mashhad \\ ${ }^{\mathrm{b}}$ Assistant Professor Department of Management, Faculty of Administrative and Economic Sciences, Ferdowsi \\ University of Mashhad \\ ${ }^{c}$ Assistant Professor Department of Management, Faculty of Administrative and Economic Sciences, Ferdowsi \\ University of Mashhad
}

\begin{abstract}
:
Researchers are recently paying attention to maintaining and strengthening customer loyalty and examining its influential factors, given that customers are the key to success and competitive advantages in today's competitive and unpredictable market. The present study aimed to investigate the effect of perceived professional ethics on customer loyalty with the mediating role of perceived reputation and trust. Customers of Asia-Pharma Company in Afghanistan were the statistical population of the study, and the data collection tool was a standard questionnaire, the reliability of which was above 0.7 on average for all research variables based on Cronbach's alpha coefficient. Data analysis and examination of research hypotheses were performed using descriptive and inferential statistics, structural equation method, and path analysis by partial least squares, along with SPSS and Smart PLS software. The research findings confirmed the hypotheses. Accordingly, professional ethics affected customer loyalty positively and significantly with the moderating role of perceived trust and reputation.
\end{abstract}

Keywords: Customer Loyalty, Customer Trust, Professional Ethics, Reputation.

\section{Introduction and Statement of Problem}

Nowadays, the role of customers has changed from producer followership to investment and production leadership. Hence, in today's competitive market, the success or failure of a business depends on the customer behavior, their reviews of their needs, the variety of goods available, and the valuation of factors such as price, desirability, quality, etc. Customer loyalty and the need to maintain it have become more important with the rapidly increasing 
competition in the business arena. As stated by scholars, customer loyalty is the most important achievement of business owners and enterprises from offering services and products to the market (Fritz et al., 2017:43).

In addition, customers and consumers are increasingly emphasizing ethics and the need for it to be met by providers of the products and services they need. Therefore, companies are required to increase the level of ethical considerations in their various sectors of production, marketing, sales, etc., while managing these demands, to prevent the negative consequences of business ethics and prevention (Lawrence et al., 2019: 71). This has made ethical issues one of the concerns of the organization because addressing the contrast between economic performance (as measured by revenues, costs, and profits) and social performance (as measured by commitments). It is the organization at home and abroad (relative to others), because it is possible that adhering to an ethical commitment to the company entails economic costs that lead to a reduction in profit margins (Omilil et al., 2017: 68). For example, some managers try to achieve a higher profit period by exploiting the labor force, reducing the quality or useful life of their products, while trusting that in the effect of such disgusting behavior is irreparable. Because, according to surveys, when an organization does its business properly and as expected, the lifespan of this fact in the public mind is five minutes. However, the effects of any abuse or breach of ethics by companies can remain in the minds of customers for years (Kim, 8: 2016).

Thus, since public perception can have a direct impact on a company's profits, another key factor that can play a role in business relationships, formal or informal, is the company's reputation for the brand, the quality of the products and services provided., Issues related to product development or even human resources (McCall et al., 67: 2018). For example, some managers try to achieve a higher profit period by exploiting the labor force, reducing the quality or useful life of their products, while trusting that in the effect of such disgusting behavior is irreparable. Because, according to surveys, when an organization does its business properly and as expected, the lifespan of this fact in the public mind is five minutes. However, the effects of any abuse or breach of ethics by companies can remain in the minds of customers for years (Kim, 8: 2016).

Thus, since public perception can have a direct impact on a company's profits, another key factor that can play a role in business relationships, formal or informal, is the company's reputation for the brand, the quality of the products and services provided., Issues related to product development or even human resources (McCall et al., 67: 2018). Ethics in the health system and considering it in providing services and products related to this field, is one of the issues that should be paid special attention. In addition to being closely related to the health of the community, this field is also related to the field of industry and trade in terms of production of drugs and diagnostic and therapeutic tools. Therefore, the purpose of this study is to investigate the impact of business ethics on customer loyalty through the mediation of reputation and trust in Asia Farm Afghanistan. In 2002, the company aims to provide quality hospital services and products to customers and help the situation Afghanistan's economy has started to trade in medical products and goods. In recent years, in addition to expanding its activities in the field of trade and import of medical goods needed for the health of Afghan society, has launched a production line of some medical products and complementary goods. Has also done in this country.

\section{Theoretical framework of research}

\section{2-1. Professional ethics and its role in customer loyalty}

In today's rapidly changing marketing environment, building strong relationships and brand loyalty with the consumer is becoming increasingly important for companies (Gholipour Soleimani, 2020: 131). Understanding the ethical value of a brand allows consumers to form certain emotions (Mapinganjira and Madoko, 2019). Previous empirical studies show that positive perceptions of the 
brand significantly contribute to customer loyalty to the brand and create emotional bonds with brands that reflect customer beliefs (Wu et al., 2017). Thus, it can be acknowledged that strong loyalty and attachment to a brand is formed when a company's products, services or brand evoke customers' memories of emotionally important experiences, events or beliefs. Therefore, those products and brands that meet the interests of customers with an ethical approach, when choosing products, because of the strong emotional bonds created between them and customers, have more choice (Wordold, 95: 2018). Studies have shown that marketing researchers examined customer loyalty from different perspectives and factors (e.g., Cassidy and Weimer, 2016; Al-Adly \& Eid, 2016; Jiang \& Zhang, 2016; Rubivat Al., 2016; Compon et al., 2016).

\section{2-2. Professional ethics and its role in brand reputation}

To improve the consumer-brand relationship and strengthen the ethical aspect of the company and the ethical relationship with customers, it is necessary to consider factors that are unique to the quality of the consumer-brand relationship. The quality of the consumer-brand relationship is an association that is created through a process in which consumers and brands, as two equal parties, participate in an market and interact with each other and interact with each other through their interaction. Pass (Ahmadi, 13: 2015). The relationship between the consumer and the brand reflects the cognitive, emotional and behavioral processes that determine the relationship between two people. Ethical marketing problems, however, occur more frequently in gray areas (such as the underground economy) where legal action can sometimes be immoral or the legitimacy or morality of the behavior is unclear. In such circumstances, the role of marketing ethics has become increasingly important. Creating relationships between brands and consumers creates a dynamic interaction between consumers and products and has a positive impact on the brand experience (Telba et al., 2015), because when consumers evaluate a brand, the quality of the relationship Evaluate by examining factors such as the perception and experience of a brand and interaction with the brand. Ethical marketing performance is one of the most visible areas in a company's diverse activities that is visible to consumers and is an important factor in consumer perception and evaluation of a brand (Lee., 2019: 78).

\section{2-3 Professional ethics and its role in perceived customer trust}

Ethics refers to "a person's moral judgment about right / wrong or good / bad." Today, companies are exposed to the public and it is constantly observed that their performance is in the right category. Consumers are also more environmentally and socially aware and vigilant. Therefore, the ethics of a company's marketing methods is an important factor that affects the perception and evaluation of a brand (Bordbar, 2014: 559). Blackstone argues that the quality of the consumer-brand relationship is a vital element in empowering consumers to trust a company and find satisfaction in its products. When consumers choose a brand, they evaluate a brand by applying emotional and relational criteria to activities, community, expectations and stories, and in the process, the consumer-brand relationship is established. Consumers evaluate the value of a brand by referring to their experience instead of focusing on the intrinsic features of a product (Benkhald, 42: 2021).

\section{2-4. Customer trust and loyalty}

Nowadays, the concept of trust and related issues has become the focus of the study of organizations and it has been well revealed to senior managers and organizational decision makers that establishing communication and cooperation between people requires trust (Frasciot et al., 2017). This is important because trust implies an understanding of how to create effective collaboration in organizations. In fact, trust is a key element to create empathy and cooperation between people that can lead to long-term relationships between the parties (Tiseng et al., 2018: 99) Dalton (2003) 
identifies three factors influencing customer loyalty: value, trust, and reputation. They expand the river. He also acknowledges that customers are loyal to people they trust, who know they are on their side, and who put their interests first. He believes that loyalty can result from the customer. If service or product providers meet the needs of customers, customers will be loyal to the company and its products. So brand loyalty means repeat purchases, which is due to psychological processes. In other words, repeat shopping is not merely an optional reaction but the result of psychological, emotional, and normative factors (Hernandez-Fernandez et al., 2019: 147).

\section{2-5. Perceived reputation and its role in customer loyalty}

Perceived reputation can be referred to as a common emotional reaction that an individual shows towards a company because of its action over a longer period of time (Loriuro et al., 2017: 63). The positive relationship between perceived reputation and customer loyalty has been examined in previous studies (Haslinda et al., 2014). Reputation has been shown to increase a company's positive sales perception, help expand its market share, and build and maintain a loyal customer base (Christo, 2003). In addition, past literature has shown that perceived reputation is one of the strongest key drivers of customer loyalty (Bentis et al., 2007). It is argued that perceived reputation management is essential for a company to maintain the long-term commitment of the buyer-seller relationship (Ballmer, 2011).

Table 1. Empirical background of the research

\begin{tabular}{|c|c|c|}
\hline Achievements & Title & researchers \\
\hline $\begin{array}{l}\text { Brand ethics have a positive effect on emotional } \\
\text { attachment to the brand as well as brand loyalty. In } \\
\text { contrast, ethical brand perceptions do not affect } \\
\text { branding goals, as individuals are recognized as instant } \\
\text { buyers who turn to other brands well. Emotional } \\
\text { attachment to the brand has a positive relationship with } \\
\text { brand loyalty and brand choice intentions and is also a } \\
\text { mediator in brand ethics and brand loyalty and brand } \\
\text { choice intention relationship. }\end{array}$ & $\begin{array}{l}\text { Brand ethics and their } \\
\text { impact on brand } \\
\text { loyalty and brand } \\
\text { selection goals: The } \\
\text { mediating role of } \\
\text { emotional attachment } \\
\text { to the brand }\end{array}$ & $\begin{array}{l}\text { Granti et } \\
\text { al. (2019) }\end{array}$ \\
\hline $\begin{array}{l}\text { Having a mixed corporate marketing strategy with } \\
\text { respect to ethical issues in creating a relationship } \\
\text { between the consumer and the brand and the quality of } \\
\text { the product is perceived, which plays a very important } \\
\text { role under the influence of loyalty to the corporate } \\
\text { brand. However, the results associated with each area of } \\
\text { ethical marketing performance - through the relationship } \\
\text { between intermediate variables and dependent reserves } \\
\text { - differ by the type of business and other characteristics. } \\
\text { Without this aspect, it is difficult to generalize the } \\
\text { current results. }\end{array}$ & $\begin{array}{l}\text { The role of ethical } \\
\text { marketing issues in the } \\
\text { consumer-brand } \\
\text { relationship }\end{array}$ & $\begin{array}{l}\text { Lee et al. } \\
(2019)\end{array}$ \\
\hline $\begin{array}{l}\text { There are three groups of loyalty antecedents that must } \\
\text { be considered. They are 1) The main determinants of } \\
\text { loyalty (PD) which include customer satisfaction, trust, } \\
\text { perceived value and perceived service quality. 2) } \\
\text { Secondary determinants of loyalty (SD), which includes } \\
\text { other loyalty factors based on the nature and context of } \\
\text { the research. And } 3 \text { ) the ethical determinants of loyalty } \\
\text { (MD), which include the spiritual, cultural, and religious } \\
\text { factors of the target markets. }\end{array}$ & $\begin{array}{l}\text { Cultural and religious } \\
\text { effects on customer } \\
\text { loyalty }\end{array}$ & $\begin{array}{l}\text { Abolhayjeh } \\
\text { et al. } \\
\text { (2018), }\end{array}$ \\
\hline $\begin{array}{l}\text { The four scenarios provided changes in corporate } \\
\text { behaviors related to the positive and negative behaviors } \\
\text { of customer social responsibility and business ethics, } \\
\text { and provided new insights into customer expectations } \\
\text { and perceptions of corporate CSR and business ethics, } \\
\text { and acknowledged that while CSR attitudes remain }\end{array}$ & $\begin{array}{l}\text { Business ethics, } \\
\text { corporate social } \\
\text { responsibility, and } \\
\text { brand attitudes }\end{array}$ & $\begin{array}{l}\text { Ferrela et } \\
\text { al. (2018) }\end{array}$ \\
\hline
\end{tabular}




\begin{tabular}{|c|c|c|}
\hline $\begin{array}{l}\text { important, But customers consider business ethics as an } \\
\text { important behavior in their understanding of brand } \\
\text { attitude. }\end{array}$ & & \\
\hline $\begin{array}{l}\text { According to the experimental valueadded variable in } \\
\text { the banking system, they found that among the } \\
\text { dimensions of empirical value added, economic value } \\
\text { and service efficiency in the relationship between seller } \\
\text { reputation and consumer behavior (loyalty and share of } \\
\text { the wallet) also play a mediating role. The hedging } \\
\text { variable also mediates between seller reputation and } \\
\text { customer loyalty. }\end{array}$ & $\begin{array}{l}\text { The relationship } \\
\text { between seller } \\
\text { reputation and } \\
\text { consumer behavior }\end{array}$ & $\begin{array}{l}\text { chegoui } \\
(2016)\end{array}$ \\
\hline $\begin{array}{l}\text { The seller's reputation has a positive and significant } \\
\text { effect on the dimensions of the seller's empirical added } \\
\text { value, as well as the superiority of service and enjoyable } \\
\text { interaction on customer loyalty as well as loyalty on the } \\
\text { share of the customer's wallet. However, the effect of } \\
\text { service superiority and the effect of enjoyable } \\
\text { interaction on the share of the wallet and the effect of } \\
\text { economic value and service efficiency on customer } \\
\text { loyalty were not confirmed. }\end{array}$ & $\begin{array}{l}\text { The effect of seller } \\
\text { reputation on the } \\
\text { dimensions of } \\
\text { empirical added value } \\
\text { and customer behavior }\end{array}$ & $\begin{array}{l}\text { Gholipour } \\
\text { Soleimani } \\
\text { et al. } \\
(2020)\end{array}$ \\
\hline $\begin{array}{l}\text { The attractiveness of the design has a positive and } \\
\text { significant effect on the brand reputation and the } \\
\text { intention of consumers to repurchase. Also, perceived } \\
\text { quality has a positive and significant effect on brand } \\
\text { reputation and consumers' intention to repurchase. The } \\
\text { positive and significant effect of subjective norms on } \\
\text { brand reputation and on consumers' intention to } \\
\text { repurchase was confirmed. The findings also showed } \\
\text { that brand popularity has a positive and significant effect } \\
\text { on brand reputation and consumers' intention to } \\
\text { repurchase. }\end{array}$ & $\begin{array}{l}\text { Evaluate the effect of } \\
\text { design attractiveness, } \\
\text { perceived quality, } \\
\text { subjective norms and } \\
\text { brand popularity on } \\
\text { consumers' repurchase } \\
\text { intention and the } \\
\text { mediating role of } \\
\text { brand reputation }\end{array}$ & $\begin{array}{l}\text { Mirzaei et } \\
\text { al. }(2020)\end{array}$ \\
\hline $\begin{array}{l}\text { The company's attention to social responsibilities and } \\
\text { behavior based on professional ethics as a competitive } \\
\text { advantage, helps the organization to establish favorable } \\
\text { relationships with customers and pave the way for } \\
\text { establishing and maintaining a two-way and lasting } \\
\text { relationship based on trust, satisfaction and mutual } \\
\text { loyalty. Helps strengthen the company's position with } \\
\text { customers and advance its overall goals }\end{array}$ & $\begin{array}{l}\text { Investigating the } \\
\text { Impact of Marketing } \\
\text { Professional Ethics on } \\
\text { Customer Loyalty }\end{array}$ & $\begin{array}{l}\text { Haji Nazar } \\
\text { et al. } \\
\text { (2014), }\end{array}$ \\
\hline
\end{tabular}

\section{2-6. Conceptual model and research hypotheses}

Considering that Heba, considering that it is necessary to conduct any field and survey research, to have a mind map and a conceptual model, in the framework of which appropriate analytical tools, variables and relationships between them have been drawn, in order to conduct the present study of the conceptual model The following is used. Accordingly, the conceptual model of the results of this study will show that professional ethics in addition to effective direct relationship with customer loyalty variable, mediated by two variables of perceived reputation and perceived customer trust also affects customer loyalty. Theoretical and studies conducted in the form of research background, framework or conceptual model of the present research are as follows: 


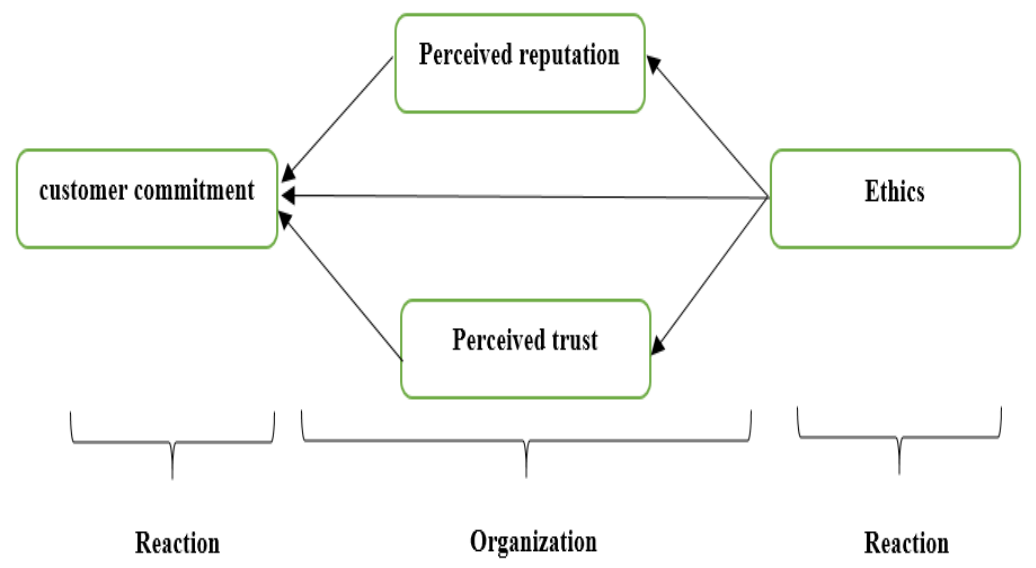

Figure 1. Conceptual model of research

\section{2-7. Research hypotheses}

1) Perceived professional ethics has a positive and significant effect on the perceived reputation of Asiafarma Company.

2) Perceived professional ethics has a positive and significant effect on the trust of Asiafarma's customers.

3) Perceived professional ethics has a positive and significant effect on the loyalty of Asiafarma's customers.

4) Perceived reputation has a positive and significant effect on customer loyalty of Asiafarma Company.

5) Perceived trust has a positive and significant effect on the loyalty of Asiafarma's customers.

6) Perceived professional ethics with the mediation of perceived reputation has a positive and significant effect on the loyalty of Asiafarma's customers.

7) Perceived professional ethics through the mediation of perceived trust has a positive and significant effect on the loyalty of Asiafarma's customers.

\section{Research methodology}

The present study is one of the types of applied research based on the positivist paradigm, which has been done in a single-section with a quantitative approach and based on a survey and correlation strategy. . The statistical population of the present study is 540 customers (including individuals, pharmacy and clinic managers, managers and marketing and sales experts of pharmaceutical companies and medical equipment) Asia Pharma Manufacturing and Trading Company, a manufacturer and distributor of medical products in Herat province of Afghanistan is constantly buying from this company. The statistical sample size was determined using Cochran's formula equal to 225 people. Gathering information to formulate the theoretical 
foundations of the research using the library method and reviewing the existing documents and resources, and in order to field the standard questionnaire based on the Likert scale has been used. In the present study, in order to ensure the validity of the research tool, standard questionnaires of professional ethics (Farlala et al., 2018) have been used. Also, in order to maintain more validity, the research questionnaire was approved by the supervisor after preparation and before distribution. Customer loyalty (Kova et al.), Perceived trust and perceived reputation (Rabab et al.), Have been used. The reliability of the Cronbach's alpha questionnaire indicates the degree of internal consistency. It is worth mentioning that in the present study, the first reliability test was performed by distributing 30 questionnaires in the statistical sample of the research and after ensuring the reliability of the research tool, the questionnaires were fully distributed.

Table 2. Results of pre-test reliability of the questionnaire

\begin{tabular}{|c|c|c|}
\hline Number of questions & Cronbach's alpha value & Component \\
\hline 4 & 0.872 & Ethics \\
\hline 5 & 0.887 & Loyalty \\
\hline 5 & 0909 & Perceived reputation \\
\hline 4 & 0.874 & Perceived trust \\
\hline
\end{tabular}

In the present study, in order to describe the collected data, various statistical indicators such as frequency, frequency percentage, types of tables and graphs have been used. For this purpose, in the inferential statistics section, in order to answer the questions and test the research hypotheses, the method of studying structural equations and path analysis using the partial least squares (PLS) method will be used. Also, in the descriptive statistics section, common statistical software such as Excel, in the inferential statistics section, Smart-PLS software has been used.

\section{Descriptive findings of the research}

Statistical description of data is a step towards identifying the pattern that governs them and a basis for explaining the relationships between variables used in research. According to the results of the first part of the questionnaire (demographic characteristics), the following information is summarized in Table 3:

Table 3. Descriptive findings

\begin{tabular}{|c|c|c|c|}
\hline $\begin{array}{l}\text { Relative frequency } \\
\text { (percentage) }\end{array}$ & $\begin{array}{c}\text { Absolute frequency } \\
\text { (number) }\end{array}$ & & \\
\hline 74 & 165 & Man & \multirow[t]{2}{*}{ Gender } \\
\hline 26 & 60 & Female & \\
\hline 7 & 17 & Less than 25 years & \multirow{5}{*}{ Age } \\
\hline 38 & 85 & Between 25 and 35 years & \\
\hline 31 & 70 & Between 35 and 45 years & \\
\hline 18 & 40 & Between 45 and 55 years & \\
\hline 6 & 13 & Older than 55 years & \\
\hline 11 & 25 & Diploma and lower & \multirow{5}{*}{ education } \\
\hline 14 & 32 & Associate Degree & \\
\hline 45 & 101 & Bachelor & \\
\hline 25 & 57 & MA & \\
\hline 5 & 10 & P.H.D & \\
\hline 19 & 42 & Less than 5 years & \\
\hline 38 & 85 & $10-5$ & \\
\hline
\end{tabular}




\begin{tabular}{|c|c|c|c|}
\hline 28 & 96 & $20-10$ & work \\
experience \\
\hline 15
\end{tabular}

\section{4-1. Inferential research findings}

\section{Check the assumption that the data is normal}

In studies performed at the level of nominal and rank scales, non-parametric tests should be used to analyze data from the Kolmogorov-Smirnov (ks) test. In this study, the Kolmogorov-Smirnov goodness-of-fit test was used to evaluate the normality of the observations. The hypothesis examined in this test is as follows:

$\mathrm{H} 0=$ There is no difference between observed and expected frequencies (distribution of observations is normal).

$\mathrm{H} 1=$ There is a difference between the observed and expected frequencies (the distribution of observations is not normal).

Table 4. Kolmogorov-Smirnov test

\begin{tabular}{|c|c|c|c|c|c|}
\hline Test result & $\begin{array}{c}\text { Statistics } \\
\mathbf{z}\end{array}$ & Meaningfulness & $\begin{array}{c}\text { Standard } \\
\text { deviation }\end{array}$ & Average & Statistics \\
\hline $\begin{array}{c}\text { Reject the null } \\
\text { hypothesis }\end{array}$ & 2.285 & 0.003 & 0.490 & 3.755 & Professional ethics \\
\hline $\begin{array}{c}\text { Reject the null } \\
\text { hypothesis }\end{array}$ & 2.504 & 0.002 & 0.677 & 3.778 & the fame \\
\hline $\begin{array}{c}\text { Reject the null } \\
\text { hypothesis }\end{array}$ & 2.173 & 0.011 & 0.619 & 3.714 & the trust \\
\hline $\begin{array}{c}\text { Reject the null } \\
\text { hypothesis }\end{array}$ & 6.123 & 0.03 & 0.492 & 3.128 & Costumer loyalty \\
\hline
\end{tabular}

According to Table (4), the significant value (Sig) for the data as well as the placement of the Zstatistic with $95 \%$ confidence level and less than 5\% error outside the range of +1.96 to-1.96 with 95\% confidence can be claimed to reject hypothesis H0. Therefore, non-parametric tests and structural equation tests can be used using Smart PLS software because the data are not sensitive to normal.

\section{4-2.Validation of research measurement tools}

The first factor that should be considered in evaluating reflective models is the one-dimensionality of the indicators. This means that each index in the index must be loaded with only one dimension or latent variable with a large factor load value. For this purpose, operating loads above $60 \%$ are introduced as acceptable. As the shape of the model can be seen in the standard coefficient estimation mode, numbers or coefficients are divided into two categories. The first category is called measurement equations, which are the relationships between latent (elliptical) variables and explicit (rectangular) variables. These equations are called factor loads. The second category is structural 
equations, which are relationships between latent and latent variables and are used to test hypotheses. In the present study, all coefficients are significant at 95\% confidence level. Therefore, the results obtained from the factor loads confirm the high validity of the model.

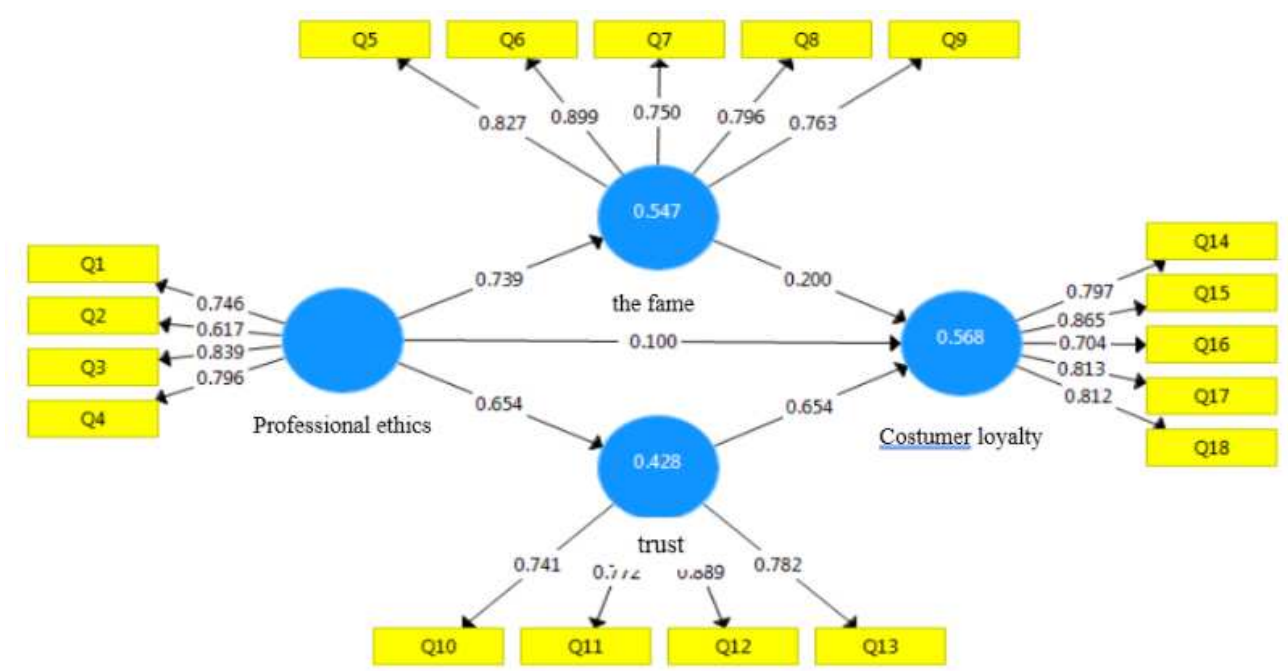

Figure 2. Research model in the case of estimating standard coefficients

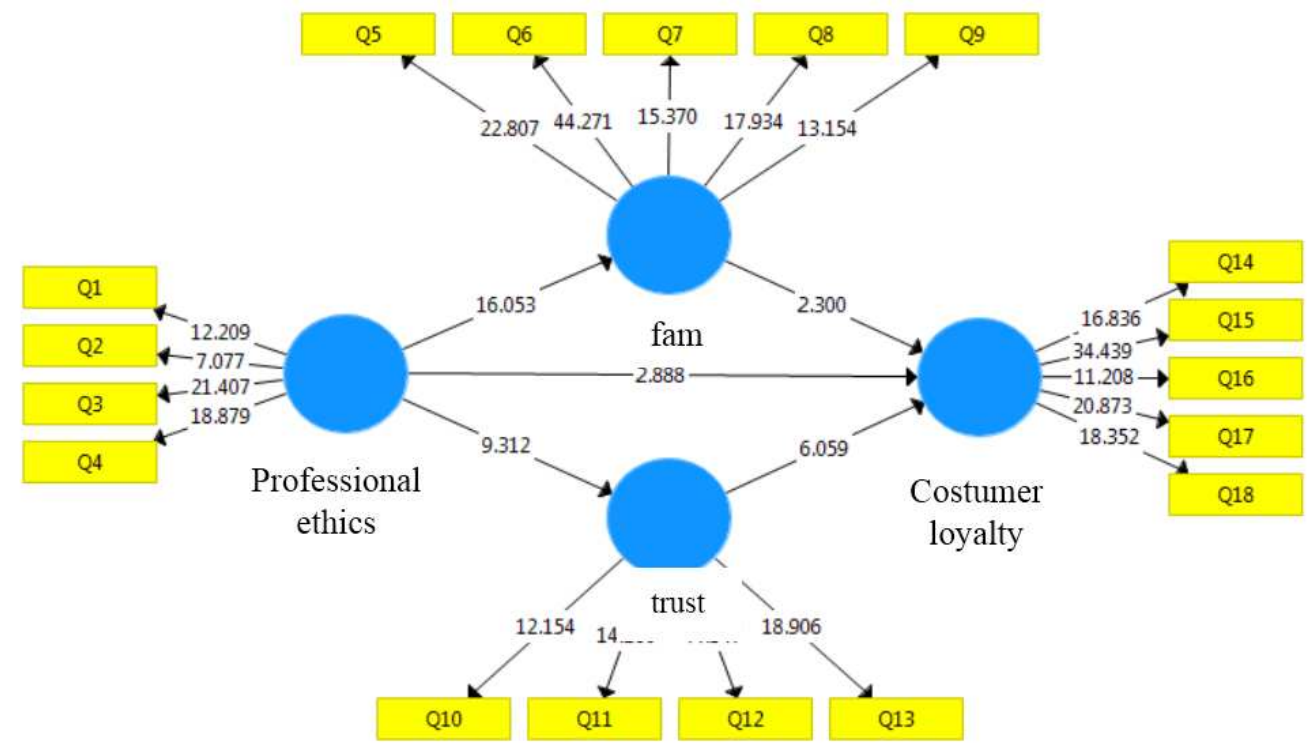

Figure 3. Significance coefficients of hypotheses in the model

Figure (2) (significance coefficients of hypotheses) shows the research models in the significant state of coefficients ( $\mathrm{t}$-value). According to the type of hypotheses expressed in the present study, naturally 
the hypotheses will be confirmed when the relevant path coefficient is positive and its significant number, which is the same as the t-statistic is significant. According to this model, the path coefficient (Figure 3) and the factor load at the 95\% confidence level are significant if the value of $t$ is outside the range $(-1.96$ to +1.96$)$ and if the value of $t$ is within this range, As a result, the factor load or path coefficient is not significant. The path coefficient and factor load are significant at the $99 \%$ confidence level if the value of the t-statistic is out of range $(-5.58$ to +5.58$)$. According to the results obtained from t-test, all factor loads were significant at $95 \%$ confidence level and played a significant role in measuring their structures.

Table 5. Reliability and validity of the measurement model

\begin{tabular}{|c|c|c|c|c|}
\hline $\begin{array}{c}\checkmark \text { AVE } \\
\text { Convergent } \\
\text { validity }\end{array}$ & AVE & $\begin{array}{c}\text { Reliability } \\
\text { Composite }\end{array}$ & $\begin{array}{c}\text { Cronbach's } \\
\text { alpha }\end{array}$ & Variables \\
\hline $0 / 754$ & $568 / 0$ & $0 / 839$ & $0 / 750$ & Ethics \\
\hline $0 / 809$ & $656 / 0$ & $0 / 904$ & $0 / 866$ & the fame \\
\hline $0 / 798$ & $637 / 0$ & $0 / 875$ & $0 / 808$ & the trust \\
\hline $0 / 800$ & $640 / 0$ & $0 / 898$ & $0 / 859$ & $\begin{array}{c}\text { Costumer } \\
\text { loyalty }\end{array}$ \\
\hline
\end{tabular}

As shown in Table (5), Cronbach's alpha values for all variables are above 0.7. Based on the obtained alpha coefficients, it can be inferred that the model has good internal consistency reliability. Regarding the calculated values of composite reliability, considering that all the calculated values are above 0.7 , the model has a good combined reliability. Also, convergent validity (AVE) according to the obtained values, considering that all AVE values for all research variables are greater than 0.5 , it can be said that the model has a good convergent validity. In addition, considering that the calculated values of divergent validity (the square root of AVE values) are located on the diameter of the correlation matrix (the table and its correlation values are larger than other variables, it can be said that the divergence validity of the model is appropriate. In Table (6), the results of the correlation of the variables with each other (AVE root values) are located on the diameter of the correlation matrix, and considering that the correlation values of that variable are larger than the other variables, so the divergence validity of the model is appropriate.

Table 6. Comparison of the AVE root of a variable with the degree of correlation of that variable with other research variables

\begin{tabular}{|c|c|c|c|c|}
\hline & Ethics & fame & trust & $\begin{array}{c}\text { Costumer } \\
\text { loyalty }\end{array}$ \\
\hline Ethics & $0 / 754$ & & & \\
\hline fame & $0 / 552$ & $0 / 809$ & & \\
\hline trust & $0 / 451$ & $0 / 601$ & $0 / 798$ & \\
\hline Costumer loyalty & $0 / 627$ & $0 / 614$ & $0 / 600$ & $0 / 800$ \\
\hline
\end{tabular}

\section{Evaluation of shaping measurement models}

One of the ways to evaluate the shaping models is the coefficient of determination (R2). The coefficient of determination (R2) examines what percentage of the variance of a dependent variable 
is explained by the independent variable (s). Therefore, it is natural that this value is equal to zero for the independent variable and greater than zero for the dependent variable. The higher this rate is, the higher the coefficient of effect of independent variables on dependents (Hanafizadeh and Zare Ravasan, 2012). According to the values listed in Figure (4), it can be said that the variables of professional ethics, reputation and trust together have been able to explain 0.568 of the variance of the customer loyalty variable; Researchers have introduced three values of $0.19,0.33$ and 0.67 as the criterion values for weak, medium and strong values of R2. Based on this, it can be concluded that the model has a high predictability's residual value is related to the prediction error and can include other factors affecting custc

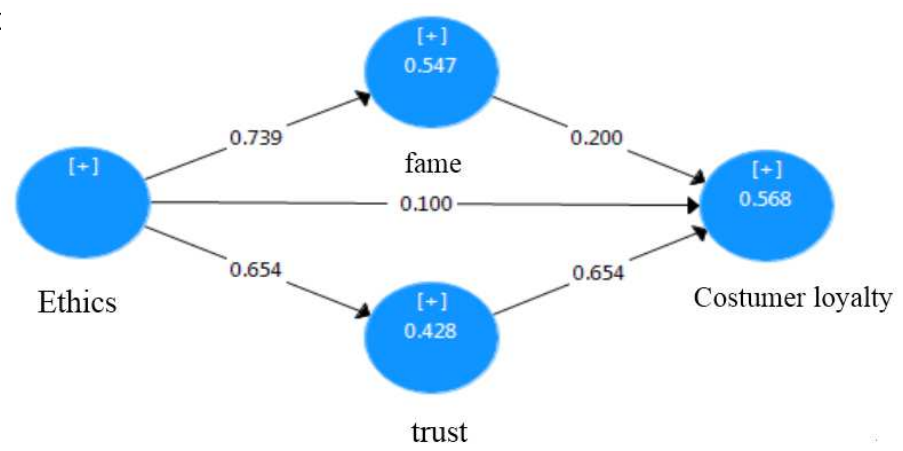

Figure 4. Evaluation of shaping measurement models

General results of research hypotheses Table 7 shows the results of all research hypotheses:

Table 7. General results of research hypotheses

\begin{tabular}{|c|c|c|c|c|}
\hline $\begin{array}{l}\text { Reject or not } \\
\text { reject the } \\
\text { hypothesis }\end{array}$ & $\begin{array}{l}\text { Significan } \\
\text { ce }\end{array}$ & $\begin{array}{c}\text { Statistic } \\
\text { s t }\end{array}$ & $\begin{array}{c}\text { Standardi } \\
\text { zed path } \\
\text { coefficien } \\
\text { t b }\end{array}$ & theories \\
\hline No rejection & Sig $<0.05$ & $2 / 888$ & $0 / 100$ & Ethics $\longrightarrow$ Costumer loyalty \\
\hline No rejection & $\mathrm{Sig}<0.05$ & $16 / 053$ & $0 / 739$ & Fame $\longrightarrow$ Ethics \\
\hline No rejection & Sig $<0.05$ & $9 / 312$ & $0 / 654$ & Ethics $\longrightarrow$ trust \\
\hline No rejection & Sig $<0.05$ & $2 / 300$ & $0 / 200$ & Fame $\longrightarrow$ Costumer loyalty \\
\hline No rejection & Sig $<0.05$ & $6 / 059$ & $0 / 654$ & Trust $\longrightarrow$ Costumer loyalty \\
\hline No rejection & Sig $<0.05$ & $\begin{array}{l}16 / 053 \\
2 / 300 \text { و }\end{array}$ & $0 / 148$ & Ethics $\longrightarrow$ of mediator of reputation \\
\hline No rejection & $\operatorname{Sig}<0.05$ & $\begin{array}{l}99 / 312 \\
6 / 059\end{array}$ & $/ 428$ & Ethics $\underset{\text { mediating role of trust }}{\longrightarrow}$ Customer loyalty with the \\
\hline
\end{tabular}

\section{5-1. Conclusions and suggestions}

The aim of this study was to investigate the effect of professional ethics on customer loyalty by mediating the role of perceived reputation and customer trust in Asia Pharma Manufacturing and Trading Company. The results of the test of research hypotheses indicate the following results: Hypothesis 1: Professional ethics has a significant effect on customer loyalty. Considering the path coefficient (0.100) and the value of $t$ statistic equal to (2.888) which is outside the range of negative 1.96 to positive 1.96 , it can be said that professional ethics has a positive effect on customer loyalty 
and It is significant that with the improvement of professional ethics, customer loyalty increases and with its decline, customer loyalty decreases. This finding is consistent with the results of studies by Grant et al. (2019), Lee et al. (2019), Abolhajieh et al. (2018), Haji Nazari and Lahouti Eshkevari (2020), et al. (2014).

Hypothesis 2: Professional ethics has a significant effect on reputation. According to the results of path coefficient (0.739) and t-value equal to (16.053) which is outside the range of negative 1.96 to positive 1.96, also diagrams (research model and significance coefficients of hypotheses in the model), Professional ethics has a significant effect on reputation, so it can be said that with the improvement of professional ethics, reputation increases and with its decline, reputation decreases. This result is consistent with the findings of studies of Achkooi (2016), Zahir et al. (2014), Gholipour Soleimani (2020)

Hypothesis 3: Professional ethics has a significant effect on trust. Considering the path coefficient (0.654) and the value of t-statistic equal to (9.312) that the value of t-statistic is outside the negative range of 1.96 to positive 1.96 and the results of diagrams (research model and significant coefficients of hypotheses in the model It can be said that professional ethics has a positive and significant effect on trust and with the improvement of professional ethics, trust increases and with its decrease, trust decreases. This finding is consistent with the results of research by Diallo et al. (2016), Haji Nazari et al. (2014), conscientious friend and colleague (2014).

Hypothesis 4: Reputation has a significant effect on customer loyalty. According to the results of path coefficient equal to (0.200) and t-statistic equal to (2.300) and graphs (research model and significance coefficients of hypotheses in the model), reputation has a significant effect on customer loyalty (external t-statistic). Is from the range of negative 1.96 to positive 1.96). Therefore, it can be said that reputation has a positive and significant effect on customer loyalty and with the improvement of reputation, customer loyalty increases and with its decrease, customer loyalty decreases. This finding is consistent with the results of studies by Ballmer (2011), Bentis et al. (2007), Mirzaei et al. (2020), Gholipour et al. (2020).

Hypothesis 5: Trust has a significant effect on customer loyalty. According to the results obtained from the path coefficient equal to $(0.200)$ and the value of t-statistic equal to $(2.200)$ which is outside the range of negative 1.96 to positive 1.96, as well as graphs (research model and significance coefficients). Hypotheses in the model), trust has a positive and significant effect on customer loyalty, so that with the improvement of trust, customer loyalty increases and with its decrease, customer loyalty decreases. This result is in accordance with the findings of Apamanio et al. (2015), Ghorbani et al. (2019), Alavijeh et al. (2015), duty-friend and colleague (2014).

Hypothesis 6: Professional ethics with a mediating role of reputation has a significant effect on customer loyalty. According to the results obtained from the path coefficient $(0.148)$ and the value of t-statistics (16.053 and 2.300) which are outside the range of negative 1.96 to positive 1.96, as well as graphs (research model and significance coefficients). Hypotheses in the model), professional ethics with the role of reputation mediation has a positive and significant effect on customer loyalty, so that with the improvement of professional ethics, customer loyalty with the role of reputation mediation increases and with it, customer loyalty with the role of mediator. Gary's reputation is declining. This finding is based on the results of studies by Mirzaei et al. (2020). 
Hypothesis 7: Professional ethics with a mediating role of trust has a significant effect on customer loyalty. Based on the value obtained from the path coefficient (0.428) and the value of t-statistic (), which is outside the negative range of 1.96 to positive 1.96, as well as graphs (research model and significance coefficients of hypotheses in the model), It can be acknowledged that professional ethics with the role of trust mediator has a positive and significant effect on customer loyalty. As professional ethics improves, customer loyalty increases with the mediating role of trust, and as it decreases, customer loyalty with the mediating role of trust decreases. This finding is consistent with the results of studies by Victoria (2018) and Wordold (2018).

\section{5-2. Practical suggestions}

Fostering customer-centric ethics and gaining the trust and commitment of the hardliners and providing a moral selling point; Attracting and employing sellers who adhere to ethical principles; Empower and nurture the ability to communicate strongly and efficiently with customers; Emphasizing the ethical charter in the organization and emphasizing the values of professional ethics.

\section{5-3. research limitations}

This research is limited to Asiafarm Afghanistan Trading and Production Company. Therefore, the generalizability of research findings requires further research. The low accuracy of the respondents in completing the questionnaires is due to ignoring the student research, which with a lot of followup and explanations of the researcher, its effect was reduced as much as possible.

\section{References}

Ahmadi, Seyed Ali Akbar and Asgari Dehabadi, Hamidreza (2015). Investigating the relationship between service quality, satisfaction, trust and loyalty among customers) Study: Passenger companies operating in Tehran terminals: Journal of Development and Transformation Management 23, pp. 11-20.

Ben Khaled, W; Gerard, B \& Farjaudon, A. L (2021). Analysis of the political and identity dynamics of dominant mode of control: The case of business ethics control and its legalization. University of Birmingham, United Kingdom; University of Paris \& University of Bordeaux, France. PP 1-18. DOI: 10.1016/j.cpa.2021.102291.

Bordbar, Behnam and Hasangholipour, Tahmourth. (2014). Ethics, the 11th key word of guerrilla marketing in academic competitions. Culture in Islamic University 13, fourth year, fourth issue, 539 .

Fritz, K., Schoenmueller, V. and Bruhn, M. (2017), "Authenticity in branding exploring antecedents and consequences of brand authenticity", European Journal of Marketing, Vol. 51 No. 2, pp. 324-348

Ferrella O.C., Dana E. Harrisonb, Linda Ferrellc, Joe F. Haird(2018). Business ethics, corporate social responsibility, and brand attitudes: An exploratory study. Journal of Business Research. https://doi.org/10.1016/j.jbusres.2018.07.039

Frasquet, Marta, and Maria-José Miquel. (2017) "Do Channel Integration Efforts Pay-Off in terms of Online and Offline Customer Loyalty?" International Journal of Retail \& Distribution Management 45 (7/8): 859-873.

Jiang, H., Y. Zhang, 2016. An investigation of service quality, customer satisfaction and loyalty in China's airline market. Journal of Air Transport Management, 57: 80-88. https://doi.org/10.1016/j.jairtraman.2016.07.008 
Haji Nazar, Siavash; Darzian Azizi, Abdul Hadi. (2014). Investigating the Impact of Marketing Professional Ethics on Customer Loyalty. First National Conference on Marketing Research.

Haslinda, H., R. A. Teo Poh Kiong, and Ainuddin. (2014) "Effects of Perceived Value and Trust on Customer Loyalty towards Foreign Banks in Sabah, Malaysia." Global Journal of Emerging Trends in e-Business 1 (2): 137-153.

Hernandez-Fernandez, Asuncion; Collin Lewis, Mathieu (2019). Brand authenticity leads to perceived value and brand trust. European Journal of Management and Business Economics Vol. 28 No. 3, 2019pp. 222-238. Emerald Publishing Limited2444-8494.

Kim, H. and Bonn, M.A. (2016), "Authenticity: do tourist perceptions of winery experiences affect behavioral intentions?", International Journal of Contemporary Hospitality Management, Vol. 28 No. 4, pp. 839-859.

Lawrence, W. T. Lo; Chan, H; Tang, F \& Yu Yeung, K. (2019). Consumer ethics: insights from business professionals. Asia Pacific Journal of Marketing and Logistics, 32(3), 664

Liu, M., Yannopoulou, N., Bian, X. and Elliott, R. (2015), "Authenticity perceptions in the Chinese marketplace”, Journal of Business Research, Vol. 68 No. 1, pp. 27-33.

Lee, Jung-Yong; chang-Hyun Jin (2019). The Role of Ethical Marketing Issues in Consumer-Brand Relationship. Sustainability 2019, 11, 6536.doi:10.3390/su11236536

McColl, J., Canning, C., Shearer, L. and McBride, L. (2018), "Vintage fashion retailing: building the store brand", in Chow, P.-S., Chiu, C.-H., Yip, A.C.Y. and Tang, A.K.Y.

Moulard, J.G., Raggio, R.D. and Folse, J.A.G. (2016), "Brand authenticity: testing the antecedents and outcomes of brand management's passion for its products", Psychology and Marketing, Vol. 33 No. 6, pp. 421-430

Tolba A, Seoudi I, Meshriki H, AbdelShahid M. (2015). Impact of ethical sales behavior, quality and image on customer satisfaction and loyalty:evidence from retail banking in Egypt. International Journal of Management and Marketing Research;8(2): 1-18.

Tseng, Timmy H. Crystal T. Lee, Facilitation of consumer loyalty toward branded applications: the dual-route perspective, Telematics Inf. 35 (5) (2018) 1297-1309.

Oumlil Ben, A \& Balloun, JL. (2017). Cultural Variations \& ethical business decision making. Journal of Business \& Industrial Marketing, 32(7), 1-41.

Qolipour Soleimani; Ali, victim of race; Maryam and the world supporter; (2020). The Impact of Vendor Reputation on Dimensions of Experimental Value Added and Customer Behavior (Case Study: Rasen Darman Co.). Journal of Human Capital Empowerment Volume 3, Number 3, pp. 203-215.

Ruiz, R. S. (2005). Relationship Outcomes of Perceived Ethical Sales Behavior: The Customer"s Perspective. Journal of Business Research, 8(4), 439-445

Ruiz, R. S. (2005). Relationship Outcomes of Perceived Ethical Sales Behavior: The Customer"s Perspective. Journal of Business Research, 8(4), 439-445

Wu, C.W., 2016. Destination loyalty modeling of the global tourism. Journal of Business Research, 69(6): 2213-2219. https://doi.org/10.1016/j.jbusres. 2015.12.032 